\title{
Corruption and Economic Development
}

\author{
Stephen J. H. Dearden \\ Manchester Metropolitan University, Department of Economics \\ Email: s.dearden@mmu.ac.uk \\ DSA European Development Policy Study Group Discussion Paper No. 18, October 2000
}

This paper discusses the relevance of economic theory to the analysis of corruption and reviews the econometric evidence for its causes and consequences. Finally it outlines the anti-corruption measures which have been taken by international organisations.

It is in many ways surprising how little attention has been paid in the academic literature to the problem of corruption in developing countries. While anecdotes may flow freely at conferences it rarely appears as an issue in formal debate. Yet with the end of the cold war and a more critical and focused view of foreign aid, the institutional, political, social, and cultural obstacles to sustained growth are now being addressed. Institution building, the rule of law and good governance are phrases that are appearing with increasing frequency in the international debate amongst policy makers. While neo-classical market economics has become the universal model and structural adjustment the means, the essential requirement of an institutional framework is now coming to be recognised. The transition of the economies of the former Soviet Union to market economies has illustrated the problems most graphically. While the Czech Republic and Poland were able to build upon their prewar experience and institutional memory, Russia has struggled to create the conditions necessary for a successful market economy. The failure to establish an independent judiciary and a framework of company law to enforce contracts, define property rights and impose accountability; to create an administration capable of honest and efficient administration and to undertake equitable and efficient tax collection, have undermined the economic recovery of the nation. The creation of effective legal structures and civil institutions requires a political will and the international community regards the commitment to democracy as the necessary and in many ways sufficient condition. Thus corruption can be seen as a manifestation of institutional failure which in turn reflects political failure, but such political failure in turn can only be explained by an analysis of the underlying forces at work in a society.

A tradition of authoritarian regimes is seen as lacking the checks and balances necessary to avoid corruption. There is no tradition of the separation of powers, of an independent and critical press, or of an independent judiciary. Even where there is the panoply of representative democratic government, where political control is based upon clientalism, political patronage or corporatism, corruption is likely to take root. A social structure characterised by a high degree of racial, tribal, religious or geographical divisions may be particularly vulnerable to political clientalism, where the ruling political elite buys its support from the groups that will sustain its power. 
The position of such groups will be reinforced by the process of corruption that gives them continued privileged access to societies resources and thereby sustains their importance to the elite that wishes to maintain control. However the conflict over the distribution of national resources in such a clientalist political system may in the long run become acute and lead to political and social disintegration, particularly in states whose legitimacy is not beyond question. Further the marginalisation of the formal legal system is the inevitable by-product of the emergence of such a political mechanism which offers privileged access, thereby undermining its legitimacy beyond the activities of the privileged elite groups.

Cartier-Bresson ${ }^{1}$ has suggested five economic conditions which appear to encourage the flourishing of corruption within a society. The existence of an exploitable natural resource (e.g. oil) providing the opportunity for State authorities, both administrative and political, to obtain payments. Secondly, the general scarcity of public assets relative to demand, accompanied by policies of fixed official prices, which creates opportunities for informal rationing through bribery. Thirdly, low wages in the public sector are also likely to be associated with extensive low-level corrupt payments. Fourthly, high levels of State intervention/planning (i.e. protectionism, State-owned enterprises, price controls, exchange controls, import licenses, etc.) which has characterised many developing countries. Finally, economies in transition are likely to have particular problems as they undertake privatisation and establish the relevant legal framework of company and contract law, etc. The relevance of these various factors is evaluated in the empirical review in the following section, however first I wish to consider in more detail the likely economic effects of extensive corruption in an economy.

\section{$\underline{\text { Analysis }}$}

Discussion about the economic costs of corruption has focused upon a number of different aspects. One approach has emphasised the cost of the diversion of resources from productive activity to avoidance of "predation". In the absence of an effective rule-of-law resources must be diverted to protect property rights. A number of authors have developed theoretical models to examine the economic consequences of such situations where protection against predation is incomplete (Ljungqvist \& Sargent 1995, Acemoglu 1995, Murphy et al 1991). They suggested the possible existence of multiple equilibria, some involving low production where diversion (i.e. theft) offers a high pay-off. The government has two roles in the prevention of predation - control is more effective if provided collectively and the government itself, in that it determines law creation and enforcement, can be a major source of diversion. Rent-seeking is the major expression of government diversion (Krueger 1974) and the principal component of what we understand by corruption.

An alternative approach has focused upon the theoretical impact of bureaucratic inefficiency upon investment and growth. In endogenous growth models such inefficiency may directly reduce investment or may lead to the misallocation of resources between capital projects. Similarly in the neoclassical growth model, such misallocation of investment may reduce the steady-state level of income and the private marginal product of capital. 
A broader economic perspective on the welfare costs arising from corruption can be obtained by focusing upon the distortions that it brings to the efficient functioning of markets. Technical, allocative and distributional efficiency will all be compromised by the various forms of price distortion in the factor and goods markets arising from corruption; we have situations of Pareto inferiority.

However it is the central role of price distortions in the welfare assessment that has lead some authors to defend the role of corruption in developing countries. In economies already characterised by substantial price distortions - wage regulation, unprofitable state-owned enterprises, state agricultural marketing boards, food subsidies, import controls, exchange controls and unsustainable exchange rates, amongst others - the rule of second best may apply. The price distortions of corruption may merely be offsetting the other state created distortions of the economy. Thus the underpayment of public sector workers may merely be offset by the opportunities offered to such workers to supplement their pay by bribery, providing incentives for the efficient discharge of their responsibilities and raising their pay to market clearing levels. Similarly the problems of rationing import licenses or allocating public contracts can be achieved through the shadow pricing of the bribes paid to obtain them. It must be remembered that welfare analysis is not concerned with issues of the distribution of income but only with the effectiveness of the pricing signals that reflect the scarcity of resources. But despite these theoretical arguments the prices that arise from these informal transactions are unlikely to be those of an efficient competitive market. Carried out secretly, without the crucial information flows of efficient markets, and with restricted participants, the correct market clearing prices cannot be established and economic welfare maximised.

Corruption has usually been defined as "the abuse of public office for private gain". This definition has been widened recently, as attention has turned to corruption within the private sector, to cover "giving or receiving undue advantage in the course of business activities leading to acts in breach of a person's duties "(Transparency 1999). However it can be argued that the role of the public sector is more significant, since it is here that the opportunities for corruption are most extensive and the public administration creates the opportunities for corruption in the private sector by creating the necessary institutional and market conditions. In both cases corruption can be viewed as an example of the Principle-Agent problem, where the core difficulty lies in the mechanism to monitor the actions of those to whom authority is delegated but where the information is possessed asymmetrically by the agent.

In creating a framework to categorise the forms of corruption we can begin by examining its impact upon the private firm or individual. Corruption can both increase or decrease the production costs faced by the firm or the product costs faced by the individual. Bribes paid to expedite government regulatory activities, to obtain import licenses or to win government contracts, will all raise costs. By contrast bribes paid to circumvent government regulations - e.g. health and safety, environmental requirements, taxation - may reduce the net cost to the company, even if it imposes social costs. In the extreme case of payments made to gain access to a valuable state resource - e.g. mining concessions, privatised enterprise - the existence of the enterprise itself may depend upon such payments. A government policy of protectionism, with Import Substituting Industrialisation, usually creates conditions of monopoly/oligopoly and therefore substantial economic rent for exploitation. 
From the perspective of the public sector costs will be both financial and economic. Corruption resulting in tax evasion will clearly reduce the government's tax revenues, but corruption may also add to the government's costs through the allocation of contracts to higher priced contractors. Such increases in prices will be essential to meet the costs of the bribes that are paid. But the economic costs may be even more substantial as projects may be undertaken merely to generate bribes rather than as a reflection of economic development priorities. Such major capital investment projects, which were never economically viable, may remain a drain on the scarce resources of developing countries for many years.

From the broadest perspective corruption distorts prices throughout the economy, as the costs of bribes are passed onto the final consumer and it creates delays in economic transactions and additional uncertainty, which may be a crucial element in undermining investment and encouraging capital flight.

\section{$\underline{\text { Empirical Studies }}$}

A large number of studies have attempted to isolate statistically both the causes and consequences of corruption; these are comprehensively reviewed in Lambsdorff (1999). Unfortunately they suffer from recurring and perhaps insurmountable problems, which while not confined to this area of study, are nonetheless particularly apparent when attempting to analyse the significance of corruption.

The first difficulty lies in attempting to establish a meaningful and robust measure of the degree of corruption present in a society. Different studies have employed a wide variety of proxies to reflect the extent of corruption, while broader corruption indices have been created by a number of institutions. One of the most comprehensive currently available is that created by Transparency International which has been published since 1995. However even this does not claim to be an objective measure of the extent of corruption but of the "perception of corruption". It draws upon several surveys of expert and general public opinion from around the world ${ }^{2}$. Qualitative assessments, with arbitrary scales, also make the interpretation of the estimated coefficient values on the corruption variable problematic. Alternatively one could look to the risk assessments of the international credit risk agencies, but the extent of corruption need not be the dominant factor in such assessments.

The second difficulty lies in the causal relationships that these studies claim to establish. Is corruption the primary cause of any statistical relationship or also a consequence (i.e. the endogeneity problem)? For example, does an association between low public sector salaries and the level of corruption reflect the undermining of the tax base to fund public expenditure (corruption causing low pay) or does it reflect the need for corrupt pay supplements to provide adequate salaries for public sector employees (low pay causing corruption). Alternately corruption and low pay may be co-determined by factors that have not been identified in the statistical analysis i.e. the political and economic interests that maintain a low tax/public expenditure regime. The final problem arises from the robustness of the other variables that are included in the studies, often leading to econometric weaknesses. 
With these general difficulties in mind we can turn to a brief review of the various factors that have been suggested as the determinates of the level of corruption and then to the efforts to identify what the economic consequences may be.

Attempts have been made to establish, amongst others, a statistical relationship between corruption and the size of the public sector, relative public sector pay levels, or the openness of the economy. But beginning with Johnson et al (1998), they considered the hypothesise that in economies where taxation and regulation of business allows discretion to officials, corruption will flourish, and firms will respond by leaving the official economy and moving into the informal sector. They examined the relationship between the share of the unofficial economy in GDP and the quality of regulation, the size of the tax burden and the level of corruption. In three separate regressions they utilised data for between 32 and 49 countries in the OECD, Latin America and the former Soviet block for the mid 1990s. Using four opinion surveys they found a positive correlation between high levels of regulation and the size of the informal economy. In their two surveys of taxation it was the perceived tax burden, rather than the level of the highest marginal tax rates, which encouraged the growth of the unofficial economy. Finally, data from six surveys confirmed the expected relationship between the extent of perceived corruption and the size of the informal sector.

However a number of difficulties arise with this study. Firstly, measuring the size of the informal sector raises serious problems. Secondly, the study also found a clear negative association between the size of the informal sector and the level of GDP. But the reduction in the size of the unofficial economy as national income increases can be explained in a number of ways. As the economy grows the resources available to the public sector may allow more effective public administration. Alternatively the relationship may be interpreted as indicating the crucial role of administrative reform in enhancing the rate of growth. Finally, both corruption and the extent of the informal economy may reflect underlying institutional weaknesses, which in turn may be determined by social and cultural influences.

Rijckeghem and Weber (1997) examined the relationship between corruption and public sector pay. In a sample of 28 developing countries they found the higher relative civil servant pay the lower the level of corruption. However other similar studies have failed to confirm the relationship.

Leite and Weidemann (1999) established a robust statistical relationship between a countries exports of oil and minerals, relative to GNP, and the level of corruption for a sample of 72 countries in 1970. The hypothesis here being that abundant natural resources, earning substantial hard currencies, provides the opportunity for rentseeking.

Ades and Di Tella (1997) examined the impact upon corruption of interventionist industrial policies, believing that they provide the opportunities for rent-seeking amongst public officials and politicians. Utilising World Competitiveness Report indices for the openness of public procurement procedures and equality of fiscal treatment between enterprises for 32 countries between 1989 and 1992, they found a negative relationship with their corruption index. This negative correlation was confirmed by the use of alternative quantitative measures of industrial interventionism 
- i.e. the size of public subsidies to public and private enterprises. They also attempted to address the causality question of whether interventionist industrial policy created opportunities for corruption, as hypothesised, or whether corrupt politicians deliberately pursued interventionism in order to create opportunities for rent extraction. Using instrumental variables to address this simultaneity bias confirmed their interpretation of the central role of interventionism in creating the conditions for corruption.

Turning specifically to the institutional dimension, studies have attempted to examine the correlation between corruption and the degree of press freedom, extent of democratic institutions, degree of political decentralisation (i.e. federalism) or the quality of the judiciary. One of the few robust studies, the 1997 World Development Report, found that its measure of the predictability of the judiciary was a significant variable in its sample of 59 countries. While Mauro (1995) found a high correlation between Business International's survey assessments of nine institutional and political aspects of 58 States. This included three dimensions of institutional efficiency corruption, bureaucracy, judicial integrity - and six measures of political stability.

Finally we can consider studies of the underlying cultural determinants. La Porta et al (1997) in a study of 33 countries using the World Value Survey, suggested that a higher incidence of "trust" in a society reduced the level of corruption; while the dominance of a hierarchical religions, such as Roman Catholicism, Eastern Orthodox or Islam, was positively associated with higher incidences of corruption. However in a subsequent study of 114 countries the relationships weakened when GDP per capita was introduced into the equations. Husted (1999) introduced the concept of "power distance" - the extent to which the less powerful members of society expect and accept unequal influence - and found it positively associated with corruption, as were the extent of dominance of materialism and the perceived threat of uncertainty. Finally Dollar et al (1999) established that the percentage of women in the labour force and in Parliament had a significantly negative effect upon the level of corruption in their study of 66 countries. However any measure of female participation in a developing countries labour force must raise serious concerns and the interpretation of the findings remains unclear. Indeed all of these studies of cultural factors raise serious problems of objective measurement.

In terms of the evaluation of the economic consequences of corruption Gupta et al (1998) examine the impact of corruption upon the distribution of income in 37 countries. They discovered a positive association between corruption and income inequality (measured by the Gini coefficient) and a negative impact of the growth of corruption upon the income growth of the bottom $20 \%$ of the income distribution. They also found that corruption may have additional indirect effects via its adverse impact upon educational opportunity and land distribution. As in some other studies the authors attempted to address the question of the direction of causation by the use of instrumental variables. However the reliability of income data, especially in developing countries and in States where corruption is high, raises serious problems, as can the use of the Gini coefficient as an accurate reflection of changes in the distribution of income.

A similar approach employing instrumental variables has been taken by Hall and Jones (1999) to address the causation relationship between productivity and 
corruption indices. Utilising data for 127 countries, compiled by Political Risk Services for the period 1986-95, they established a strong relationship between the level of output per worker and their measure of "social infrastructure". This index included assessments of law and order, bureaucratic quality, risk of expropriation and repudiation of contracts and corruption. The primary role of social infrastructure was tested by employing the geographical and linguistic characteristics of the countries as instrumental variables. Other studies have focused upon the influence of corruption on the level of GDP per capita (Kaufman et al (1999)) and upon the rate of growth of GDP. Keefer \& Knack (1995), Poirson (1998) and Leite \& Weidmann (1999) all confirmed the significance of corruption levels for growth rates.

Mauro (1995) identified reduced investment as the mechanism whereby growth was reduced by the influence of corruption. Utilising data from Business International for the period 1980-85 for 58 countries Mauro employed nine country assessment categories, grouped into indices of bureaucratic efficiency, political stability and overall institutional efficiency, so as to reduce measurement error. The bureaucratic index consisted of assessments of the efficiency of the bureaucracy, judiciary and of the incidence of corruption. Both the bureaucratic index and corruption alone were found to be negatively correlated with the rate of investment, even while controlling for other significant variables. To test for the endogeneity of these variables Mauro employed a measure of national linguistic homogeneity (Ethnolinguistic Fractionalisation), confirming the causal relationship. As investment is an important determinant of growth Mauro proceeded to examine the relationship between corruption and growth. Both the corruption index and the bureaucratic efficiency index were significantly related to per capita GDP growth over the period 1960-85, although the results were less robust than in the case of the relationship to investment. But more importantly once investment was introduced into the growth equations the bureaucracy and corruption indices became insignificant.

Ades and Di Tella (1997) also examined the impact of corruption upon investment and found that it reduced the positive impact of interventionist policies upon investment by between $16 \%$ and $72 \%$. A number of other studies, using different indexes of corruption, have confirmed these results (e.g. Keefer \& Knack 1995). This suggests that the primary economic impact of corruption may be as a deterrent to investment rather than in reducing the productivity of capital once an investment is made. However problems of heteroscedasticity (the probability distribution of the disturbance term is not constant) have often compromised many of the estimates.

But other authors regard the predictability of the corruption as a more important influence upon investment than the overall level. The World Development Report (1997) identified the importance of this factor. Campos et al (1999), utilising the same World Bank survey data, carried out a cross-section study of 69 countries for the years 1990-94. Controlling for GDP per capita and secondary school enrolments - as a measure of human capital investment - they found that the perceived unpredictability of corruption was a more robust and significant determinant of the rate of investment than the extent of corruption. Thus he argued countries with extensive, but predictable corruption, would deter less investment than those with similarly high levels of corruption where payments could not guarantee the desired outcome. However his measures of the predictability of corruption and its extent were highly correlated with each other and the overall explanatory power of his equations very weak. Campos 
also recognises that more stable institutionalised corrupt regimes might well present even greater obstacles to reform in the longer term than those that are unpredictable. He suggests just such a situation may be facing some of the countries of East Asia. The conclusion that a category of stable but corrupt regimes can exist must also be reconciled with evidence such as that of Mauro (1995) who found a high correlation between his measures of political instability and bureaucratic inefficiency, including corruption.

Corruption may also have an impact upon the flow of foreign resources to a country whether as foreign investment or as aid. Unfortunately the evidence is rather mixed. Whereas Wei (1997) detected a significant negative effect in a study of the capital flows between 14 source and 45 recipient countries between 1990 and 1991, Wheeler and Mody (1992) and Alesina and Weder (1999) found that corruption was an insignificant determinant of foreign direct investment. Alesina and Weder also found that corruption appeared to have no influence upon the flows of aid from OECD donors. However focusing upon bilateral aid flows they suggest that the Scandinavian donors did appear to be sensitive to the corruption levels of recipient countries, while the flow of US aid appeared to be positively associated with their corruption measure.

Although attempts at the econometric evaluation of the origins and consequences of corruption present considerable methodological problems, some tentative conclusions can be drawn. There is confirmation that corruption is encouraged in economies with substantial export earnings from a natural resource or where the State is interventionist, as suggested by Cartier-Bresson. Corruption is also strongly associated with inefficient public administration and an ineffective judicial system. Whether these institutions have been compromised to provide the means for corruption or are themselves a manifestation, like corruption itself, of underlying political and social conditions, remains to be considered. The economic consequences of extensive corruption include low labour productivity, reduced investment and consequently lower growth. The distribution of income is also likely to be more unequal.

$\underline{\text { The International Institutions }}$

\section{OECD}

So far the most significant international agreement addressing the problem of corruption has been that of the OECD "Convention on Combating Bribery of Foreign Public Officials in International Business Transactions". This was adopted in November 1997 and came into force in February 1999. So far 17 countries, including seven within the EU, have ratified the Convention which requires the signatories to make it a criminal offence to offer bribes in order to obtain a business advantage. It also encourages States to end the ability of firms to treat bribe payments as business costs that are tax deductible. The success of these measures is being monitored by an OECD Working Group on Bribery in International Business Transactions.

The OECD, the EU and G7 are also collaborating in the fight against money laundering. The Inter-governmental Financial Action Task Force (FATF) is composed of representatives from all of the major international financial centres and produces recommendations for anti-money laundering legislation and procedures. FATF 
reviews compliance with these recommendations and is assisting in the establishment of similar agreements in other regions of the world. One such has already been established in the Caribbean.

Similarly in 1998 the UN had published a report on Money Laundering, followed in 1999 by another initiative, the "Offshore Initiative" of the UN Global Programme against Money Laundering. This identified a "white list" of well regulated Offshore Financial Centres that were cooperating with the international organisations. Those not included were to be encouraged to adopt anti-money laundering legislation and to increase their cooperation. By contrast in 1998 the OECD had published a Report on Unfair Tax Competition that had identified a "black list" of tax havens that facilitate unfair international tax competition. Interestingly Switzerland and Luxembourg declined to sign up to the OECD report and are therefore not liable to listing.

Pressure on the approximately fifty offshore tax havens has been mounting. Within the EU's jurisdiction the tax policies of the Isle of Man, Jersey and Guernsey have been found to be harmful and could be required to be amended by 2003. Many of the "black listed" OFCs face the threat of economic sanctions by the OECD. This will raise serious problems for a large number of island economies, such as the Marshall Islands, Seychelles, Bermuda and the British Overseas Territories of the Caribbean, for whom offshore financial activity is an important source of revenues. In response CARICOM is taking the actions of the OECD in regard to tax havens and the FATF on money laundering to the WTO.

\section{The Council of Europe}

The Council of Europe has also adopted two conventions covering Criminal and Civil Law. These cover Central and Eastern Europe as well as the EU. The Criminal Law Convention extends the definition of corruption to include the activities of the private sector, while the Civil Law Convention provides for compensation for individuals suffering a loss as a result of corrupt practises by an official. Both Conventions provide protection for "whistleblowers". So far 12 Member States of the EU have ratified the Criminal Law Convention and only 5 the Civil Law Convention. The EC will be able to accede to the Conventions in its own right once the Conventions come into force.

\section{The European Community}

Within the EU two anti-corruption Conventions have been drafted. The July 1995 Convention is concerned with the protection of the ECs financial interests and the May 1997 Convention with corruption amongst EC officials or officials of the Member States. However neither has been ratified by a large number of its Member States. Public Procurement within the EU has been subject to review (COM(98)143), with the possibility of the introduction of anti-corruption pledges by all parties to contracts, as has the role of the Statutory Auditor.

In terms of the EU's external relations the Common Service Relex, which is responsible for executing most of the EU' development aid programme, has adopted "ethical clauses" in its Manual of Procedural Rules for its procurement procedures. The possibility of "blacklisting" companies or individuals who infringe these rules 
has, for the first time, been introduced. Unfortunately this Manual only covers the contracting phase and complementary rules covering the implementation phase have yet to be adopted. The Commission has however taken general powers to suspend or cancel aid if partner governments fail to take satisfactory action to combat corruption when it is discovered.

The abolition of the tax deductibility of bribes, which had been a frequent practice within EU States, will be required with the adoption of thee OECD Convention. Associated with this practice has been the issue of the treatment of the costs of bribery as part of Export Credit Insurance. Bribery has been estimated to add 10\% to 20\% to the costs of any contract and these export guarantees are usually ultimately government funded. As the EU has competence in regard to external trade responsibility clearly falls upon the Commission to instigate action in this area.

The heightened priority being given by the EU to the problem of corruption in developing countries and the general approach that is being taken, is best illustrated by examining the new Partnership Agreement (Cotonou) between the EU and the ACP states that succeeded the Lomé Conventions in 2000. In this Agreement "the respect for human rights, democratic principles and the rule of law" are regarded as "essential elements of the partnership" while a commitment to "good governance" is a further "fundamental element". In Article 8, where the process of "political dialogue" is outlined, specific reference is made to the "regular assessment of the developments concerning the respect for human rights, democratic principles, the rule of law and good governance." Under Article 9 the Agreement recognises that "democracy based upon the rule of law and transparent and accountable governance are an integral part of sustainable development". Specifically "the structure of government and the prerogative of the different powers shall be founded on the rule of law, which shall entail in particular effective and accessible means of legal redress, an independent legal system guaranteeing equality before the law and an executive fully subject to the law." Good governance is defined as "the transparent and accountable management of human, natural, economic and financial resources for the purpose of equitable and sustainable development. It entails clear decision making procedures at the level of public authorities, transparent and accountable institutions, the primacy of law in the management and distribution of resources and capacity building for elaborating and implementing measures aiming in particular at preventing and combating corruption."(Article 9.3)

The introduction of good governance into the Agreement had faced considerable opposition from the ACP States. As Adamou Salao of Niger commented "the main contention concerns its inclusion as an essential element in the future agreement ... none of the ACP countries want to see good governance become an essential element, which if violated would trigger the non-execution clause and potentially lead to sanctions" (The Courier No.177 Oct-Nov. 1999). The ACPs were willing to strengthen the political dialogue, affirming their "adherence to the principles of democracy, the rule of law, human rights and good governance. Nonetheless these principles should not be used by the EU to suspend development assistance unilaterally or render it conditional" ${ }^{3}$. The result of the negotiations was a compromise solution distinguishing between "essential" (i.e. human rights, democracy, rule of law) and "fundamental" (i.e. corruption) elements of the Agreement, with two separate procedures created to address cases where there has 
been violation of these principles. In the case of corruption there is a consultation procedure and a strong reserve power for the EC - "in cases of special urgency appropriate measures may be taken without prior consultation". The Agreement is qualified, - only "serious cases of corruption, including acts of bribery leading to such corruption, as defined in Article 97, constitute a violation of the Agreement". But "if the consultations do not lead to a solution acceptable to both Parties or if consultation is refused, the Parties shall take the appropriate measures. In all cases, it is above all incumbent on the Party where the serious cases of corruption have occurred to take the measures necessary to remedy the situation immediately. The measures taken by either Party must be proportional to the seriousness of the situation. In the selection of these measures. priority must be given to those which least disrupt the application of this agreement. It is understood that suspension would be a measure of last resort" (Article 97.3).

The Agreement also qualifies the regular assessment of the ACPs progress in the "promotion of human rights, processes of democratisation, consolidation of the rule of law and good governance" in that it is to "take account of each country's economic, social, cultural and historical context."(Article 9.4).

\section{$\underline{\text { Conclusion }}$}

Although the international aid organisations can make a significant contribution to the erosion of the endemic corruption that is compromising the economic development of many countries, ultimately it is the level of commitment to reform within the countries themselves that is crucial._For progress to be made political commitment to "good governance" within the developing countries is crucial. This will ensure that the elements necessary for what Transparency International has termed a "National Integrity System" can be put in place. These elements include an independent judiciary, political pluralism with an accompanying effective opposition, appropriate anti-corruption legislation, effective monitoring and auditing systems (including paralegal independent inspectorates and administrative commissioners), structures to ensure integrity in the awarding of public contracts, the encouragement of the monitoring role of civil society through the establishment of an independent press, and the "declaration of interests" by both politicians and civil servants.

The international community can encourage these developments by a programme of technical assistance and targeted aid. For institution building to be successful it is essential that there be a political commitment in the developing countries. The international donors must be willing to reward such political commitment to reform and penalise those States whose governments fail to meet these international standards. But it must be recognised that significant difficulties may arise in the attempt to objectively and consistently assess the progress of the recipient states. Some institutions, such as the World Bank, believe that there is a high correlation between simple quantitative indicates and progress in general reform. For the EU the Cotonou Agreement's requirement for the regular assessment of the ACPs progress in achieving reform will quickly bring this issue to the fore. It will be essential to assuage the ACPs fear that such assessments may be arbitrary or politically motivated. The EU at least has the advantage of more diluted political interests and a greater degree of overt dialogue than the situation in many individual Member States. 
The Cotonou Agreement also provides considerable flexibility in the operation of its "corruption clause" while retaining sanctions in the case of serious infringements.

The difficulties that such fundamental transformations present for many developing States must also be recognised and an appropriate long-run perspective adopted. For example, the pressure upon public sector budgets arising from structural adjustment programmes can exacerbate the problem of low pay in the civil service, encouraging corruption. The emphasise upon "partnership" in much of the debate is a clear recognition of the nature of the challenge that reform offers. But in those cases where the existing political elite is unresponsive then donors have already identified the crucial role that will have to be played by other actors in the developing countries "civil society". This strategy of by-passing unsatisfactory governments has yet to be tested. The political difficulties of fostering other "actors" in a society may be considerable, perhaps compromising their relationship with their own domestic governments. It also fails to address the problem of those civil societies where such "actors" do not exist. But the developed countries also have a clear responsibility to create an international environment that discourages corrupt practices. The recent moves by the OECD and the EU to make the offering of bribes by international companies illegal is an indication of significant progress and a clear demonstration of a commitment that the international community can now require the developing world to reciprocate.

Endnotes

1. A general non-technical review of the issues involved in the debate about corruption can be found in a series of articles in The ACP-EU Courier, No 177, October 1999. It is also available at http://www.europa.eu.int/comm/development/publicat/courier/index_177_en.h $\underline{\mathrm{tm}}$

2. Documentation for the Transparency International Corruption Perception Index can be found at http://www.uni-goettingen.de/ uwvw

3. 3. Para.84 : ACP Group Negotiating Mandate, Brussels, 30 September 1998. Available at http://www.oneworld.org/acpsec/gb/lome/future/negman_e.htm

\section{Bibliography}

Acemoglu D. 1995. Reward Structures and the Allocation of Talent : European Economic Review Vol. 39, pp.17-33

Ades A. \& Di Tella R. 1997. National Champions and Corruption, Some Unpleasant Interventionist Arithmetic : The Economic Journal Vol. 107 pp. 1023-1042

Alesina A. \& Weber B. 1999. Do Corrupt Governments Receive Less Foreign Aid? : National Bureau of Economic Research Working Paper 7108

Campos J, Lien D. \& Pradhan S. 1999. The Impact of Corruption on Investment; Predictability Matters : World Development Vol. 27 pp. 1059-67. 
Dollar D. et al 1999. Are Women Really the "Fairer Sex"? Corruption and Women in Government : Policy Research Report on Gender and Development, Working Paper No4, The World Bank, Washington.

Gupta S., Davoodi H. \& Alonso-Terme R. 1998. Does Corruption Affect Income Inequality and Poverty? : International Monetary Fund Working Paper 98/76

Hall R. \& Jones C. 1999. Why Do Some Countries Produce So Much More Output Per Worker than Others: Quarterly Journal of Economics Vol 114 pp. 83-116.

Husted 1999. Wealth, Culture and Corruption : Journal of International Business Studies Vol. 30 (2) pp 339-60

Johnson S. et al. 1998. Regulatory Discretion and the Unofficial Economy : The American Economic Review Vol. 88, pp. 387-92

Kaufmann D. et al 1999. Governance Matters : World Bank Policy Research Working Paper 2196.

Keefer P. \& Knack S. 1996. Institutions and Economic Performance, Cross-Section Tests Using Alternative Institutional Measures : Economics and Politics, Vol 12 pp. 207-27

Krueger A. 1974. The Political Economy of the Rent-Seeking Society : American Economic Review Vol. 64 pp. 291-303

Lambsdorff J. G. 1999. Corruption in Empirical Research - A Review : Transparency International Working Paper.

La Porta et al 1997. Trust in Large Organisations : The American Economic Review, Vol. 137 (2), pp 333-8.

La Porta et al 1999. The Quality of Government : The Journal of Law, Economics and Organisation, Vol. 15 (1) pp 222-79

Leite C. \& Weidmann J. 1999. Does Mother Nature Corrupt ? Natural Resources, Corruption and Economic Growth : International Monetary Fund Working Paper $99 / 85$

Ljungqvist L. \& Sargent T. 1995. The Swedish Unemployment Experience : European Economic Review Vol. 39 pp. 1043-1070

Mauro P. 1995. Corruption and Growth : Quarterly Journal of Economics Vol. 110 pp. $681-712$

Mauro P. 1997. The Effects of Corruption on Growth, Investment and Government Expenditure; A Cross Country Analysis: in Corruption and the Global Economy, Institute for International Economics, Washington. 
Murphy K., Shleifer A. \& Vishny W. 1991. The Allocation of Talent, Implications for Growth : Quarterly Journal of Economics Vol. 106 pp. 503-530

Poirson H. 1998. Economic Security, Private Investment and Growth in Developing Countries : International Monetary Fund Working Paper 98/4

Rijckeghem C. \& Weber B. 1997. Corruption and the Rate of Temptation. Do Low Wages in the Civil Service Cause Corruption? : International Monetary Fund Working Paper 97/73.

Transparency International 1999. Fighting Corruption: What Remains to be Done at EU Level : Working Paper.

United Nations Development Programme 1997. Corruption and Integrity Improvement Initiatives in Developing Countries.

Wei S. 1997. How Taxing is Corruption on International Investors : National Bureau of Economic Research Working Paper 6030

Wheeler D. \& Mody A. 1992. International Investment Location Decisions, The Case of US Firms : Journal of International Economics Vol. 33 pp. 57-76 